\title{
Penerapan Model Pendidikan Gerak Aktivitas Lokomotor dan Pemberian Spesifik Feedback untuk Meningkatkan Keterampilan Melompat
}

\author{
Hisam Safa' ${ }^{1}{ }^{1}$, Andi Suntoda $^{1}$, Agus Mahendra $^{1}$ \\ ${ }^{1}$ Program Studi Pendidikan Guru Sekolah Dasar Pendidikan Jasmani, Universitas Pendidikan Indonesia
}

\begin{tabular}{|c|c|}
\hline Info Artikel & Abstrak \\
\hline $\begin{array}{l}\text { SejarahArtikel: } \\
\text { Diterima November } 2018 \\
\text { Disetujui April } 2019 \\
\text { Dipublikasikan Mei } 2019\end{array}$ & $\begin{array}{l}\text { Penelitian ini bertujuan untuk menerapkan model pendidikan gerak dan pem- } \\
\text { berian spesifik feedback dalam pembelajaran pendidikan jasmani pada siswa } \\
\text { kelas } 3 \text { Sekolah Dasar dengan maksud untuk meningkatkan keterampilan me- } \\
\text { lompat siswa. Metode yang digunakan dalam penelitian ini adalah Penelitian }\end{array}$ \\
\hline Keywords: & $\begin{array}{l}\text { pel penelitian adalah } 39 \text { siswa kelas } 3 \text {. . Untuk mengukur keterampilan me- } \\
\text { lompat, digunakan tes keterampilan performance checklist. Hasil penelitian }\end{array}$ \\
\hline $\begin{array}{l}\text { Model Pendidikan Gerak, Keterampi- } \\
\text { lan Melompat, Specific feedback }\end{array}$ & $\begin{array}{l}\text { menunjukan bahwa terdapat peningkatan keterampilan melompat sebesar } \\
43 \% \text { dari observasi awal hingga siklus II tindakan } 2 \text {. Dapat disimpulkan bah- } \\
\text { wa penerapan model pendidikan gerak aktivitas lokomotor melalui pemberian } \\
\text { spesifik feedback dapat meningkatkan keterampilan melompat siswa kelas } 3 \\
\text { Sekolah Dasar di Kota Bandung. Penelitian ini diharapkan dapat memberikan } \\
\text { informasi mengenai pentingnya feedback dalam mempercepat proses pem- } \\
\text { belajaran gerak. }\end{array}$ \\
\hline
\end{tabular}

\begin{abstract}
The aim of this research is to assess effectiveness of movement education model and specific feedback provision in teaching locomotor activities to third grader of Elementary School. This research was employing Classroom Action Research approach with involving 2 cycles, each of which using two meeting actions. The instrument to be used in detecting the improvement was a jumping skill performance checklist. The participants for this research were 39 students from third grade of Elementary School. The result indicated that students' jumping skills were increasing for about $43 \%$ from pre-test to the end cycle. It can be concluded that giving feedback in the learning process has optimized students' improvement in their jumping skills.
\end{abstract}




\section{PENDAHULUAN}

Pendidikan adalah suatu proses yang ditujukan untuk membina kualitas sumber daya manusia seutuhnya agar dapat melakukan perannya dalam kehidupan secara fungsional dan optimal (Elmubarok, 2009). Pendidikan dapat dilaksanakan secara formal dan informal. UU RI No. 20 Tahun 2003 pasal 1 ayat 1 menyebutkan bahwa pendidikan formal adalah jalur pendidikan yang terstruktur dan berjenjang yang terdiri atas pendidikan dasar, pendidikan menengah dan pendidikan tinggi.

Salah satu komponen untuk berlangsungnya proses pendidikan adalah adanya peserta didik atau siswa. Pertumbuhan dan perkembangan peserta didik dapat tercapai melalui proses pembelajaran di sekolah, salah satunya melalui pembelajaran pendidikan jasmani. Pendidikan jasmani adalah proses belajar untuk bergerak, dan belajar melalui gerak (Faridah, 2016). Terdapat banyak materi dalam konteks pembelajaran pendidikan jasmani di sekolah dasar yang terdapat dalam kurikulum, salah satu materinya yaitu aktivitas lokomotor.

Pada dasarnya aktivitas lokomotor termasuk ke dalam kategori gerak dasar fundamental. Aktivitas lokomotor yaitu jenis gerakan yang ditandai dengan pergerakkan seluruh tubuh dalam proses perpindahan tempat atau titik berat badan dari satu bidang tumpu ke bidang tumpu lainnya, seperti berjalan, berlari, melompat, jingkat, berderap, melangkah, bergeser, dll. (Agustini et. al, 2016).

Aktivitas lokomtor untuk kelas 3 Sekolah Dasar dalam Kurikulum 2013 adalah menerapkan dan mempraktikan prosedur gerak kombinasi pola gerak dasar lokomotor sesuai dengan konsep tubuh, ruang, usaha, dan keterhubungan dalam berbagai bentuk permainan sederhana dan atau tradisional. Sejalan dengan apa yang telah dipaparkan di atas siswa harus menguasai pola gerak dasar lokomotor sesuai dengan konsep tubuh, ruang, usaha, dan keterhubungan. Namun, pada kenyataan di lapangan tidak banyak siswa yang terampil dalam melakukan aktivitas lokomotor, khususnya melompat. Banyak anak yang tidak menguasai keterampilan melompat, yang jika dinilai secara cermat akan menunjukkan nilai yang kurang memadai dalam dalam aksi atau keterampilan melompatnya.

Kelemahan tersebut dapat disebabkan oleh berbagai faktor, diantaranya karena model pembelajaran yang digunakan kurang bervariasi, atau cenderung monoton, serta guru kurang memperhatikan anak sesuai kebutuhan dan perkembangannya. Dari faktor siswa, banyak siswa yang tidak berminat mengikuti pelajaran, sehingga aktivitas belajar mereka dalam penjas tidak sungguh-sungguh, serta kurang mendapatkan koreksi yang spesifik terkait keterampilan gerak yang sedang dipelajari.

Untuk mengatasi permasalahan di atas, banyak cara yang dapat dilakukan, salah satunya dengan penerapan model pendidikan gerak serta pemberian feedback. Model Pendidikan gerak (movement education) adalah model pembelajaran dalam penjas yang menekankan pada pengajaran konsep dan komponen gerak (Mahendra, 2017). Dalam model pendidikan gerak, anak tidak diajarkan mengenai istilah-istilah yang berhubungan dengan olahraga. Selain dengan menggunakan model pendidikan gerak guru juga harus memberikan umpan balik atau feedback. 
Feedback atau umpan balik yaitu suatu tindakan yang diberikan oleh pendidik dalam hal ini guru untuk membantu anak didik/ murid dalam memahi suatu pembelajaran dengan cara menanggapi hasil suatu pembelajaran atau pekerjaan yang dilakukan sampai anak didik/murid menguasai materi yang disampaikan oleh gurunya (Windarsih, A, 2016). Feedback dilakukan dengan cara guru mengobservasi anak secara individu dan menilai bagaimana siswa melakukan aktivitas serta memberi perintah atau menjelaskan apa yang harus diperbaiki untuk meningkatkan kemampuan siswa tersebut (Suherman, 2009). Pemberian jenis umpan balik harus disesuaikan dengan kebutuhan siswa. Kurang sesuainya jenis umpan balik yang diberikan akan berdampak kepada perasaan tidak enak, pesimistis, tidak memiliki motivasi, atau tidak memiliki harga diri karena selalu mendapat teguran guru (Budiman, 2009).

Karena itu salah satu bentuk feedback yang diberikan yaitu spesifik feedback. Spesifik feedback adalah pemberian informasi yang menyebabkan anak mengetahui apa yang harus mereka lakukan dan mengetahui bagaimana seharusnya mereka lakukan dan mengetahui bagaimana seharusnya mereka berlatih. (Suherman, 2009)

Model yang sangat tepat digunakan oleh guru dalam menyampaikan materi ajar, yaitu model pendidikan gerak. Karena sifatnya yang eksploratif, yaitu lebih menuntut siswa aktif dalam mencari pengembangan gerakan yang diperintahkan oleh guru, serta kesempatan guru untuk mencontohkan gerakan lebih sedikit. Selain model yang digunakan ada juga faktor lainnya, yaitu pemberian umpan balik oleh guru. Ini sangat penting, karena dengan memberikan umpan balik guru akan menjadi tahu sejauh mana materi yang disampaikan dapat diterima oleh siswa, dan juga dengan adanya umpan balik, komunikasi antara guru dengan siswa dapat terjalin. Sehingga dapat memudahkan guru dalam menjalin hubungan sosial. Selain itu umpan balik atau feedback memainkan peranan penting dalam percepatan belajar siswa.

\section{METODE PENELITIAN}

Metode yang sesuai dengan permasalahan yang diteliti adalah metode Penelitian Tindakan Kelas (Arikunto, 2006). Teknik yang digunakan untuk mengumpulkan data dalam penelitian ini adalah teknik tes keterampilan melompat dari (Aloysius, dkk, 2014). Setelah data terkumpul, data tersebut diolah dalam bentuk PAN dan persentase. Populasi dari penelitian ini yaitu seluruh siswa kelas 3 yang berjumlah 156 siswa, sedangkan sampel yang digunakan dalam penelitian ini sebanyak 39 siswa.

\section{HASIL PENELITIAN}

Dalam observasi awal, peneliti mendapatkan gambaran awal bahwa keterampilan melompat siswa berada pada prosentase 51\%. Hasil prosentase pada observasi awal tersebut mengindikasikan bahwa keterampilan melompat siswa dalam ketegori rendah. Kondisi itulah yang mendorong peneliti untuk menerapkan model pendidikan gerak aktivitas lokomotor dan pemberian spesifik feedback. Berikut hasil dari observasi awal hingga siklus II tindakan 2. 


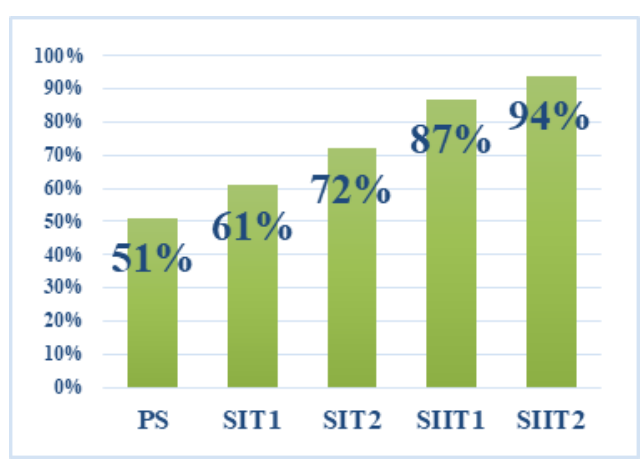

Gambar 1. Diagram Presentase Keberhasilan Siswa.

Hasil penelitian Siklus I (Tindakan I) penilaian keterampilan melompat mencapai jumlah 236 dengan rata-rata 6,1 dan perolehan prosentase yang dicapai $61 \%$. Dari hasil tersebut, dapat dilihat bahwa keterampilan melompat siswa dengan menerapkan model pendidikan gerak aktivitas lokomotor melalui pemberian spesifik feedback mengalami peningkatan walau masih di dalam kategori kurang. Hal demikian dapat kita lihat dari naiknya nilai prosentase penilaian keterampilan melompat dari $51 \%$ menjadi $61 \%$.

Hasil penelitian Siklus I (Tindakan II) keterampilan melompat mencapai jumlah 281 dengan rata-rata 7,2 dan perolehan prosentase yang dicapai $72 \%$. Dari hasil tersebut, dapat dilihat bahwa keterampilan melompat siswa mengalami peningkatan walaupun masih di dalam kategori kurang. Hal demikian dapat kita lihat dari naiknya nilai prosentase keterampilan melompat dari $51 \%$ menjadi $72 \%$.

Hasil penelitian Siklus II (Tindakan I) keterampilan melompat mencapai jumlah 339 dengan rata-rata 8,7 dan perolehan prosentase yang dicapai $87 \%$. Dari hasil tersebut, dapat dilihat bahwa keterampilan melompat siswa mengalami peningkatan. Hal demikian dapat kita lihat dari naiknya nilai prosentase penilaian praktek gerak manipulatif dari 51\% menjadi $87 \%$.

Hasil penelitian Siklus II (Tindakan II) keterampilan melompat mencapai jumlah 368 dengan rata-rata 9,4 dan perolehan prosentase yang dicapai $94 \%$. Dari hasil tersebut, dapat dilihat bahwa keterampilan melompat siswa mengalami peningkatan. Hal demikian dapat kita lihat dari naiknya nilai prosentase penilaian praktek gerak manipulatif dari 51\% menjadi $94 \%$.

Berdasarkan hasil penelitian dari mulai observasi awal atau pra-siklus hingga ke siklus II (tindakan 2), diketahui bahwa penerapan model pendidikan gerak aktivitas lokomotor dan pemberian spesifik feedback dapat meningkatkan keterampilan melompat siswa.

\section{PEMBAHASAN}

Pada siklus I tindakan I, peningkatan keterampilan melompat siswa melalui model pendidikan gerak aktivitas lokomotor melalui pemberian spesifik feedback meningkat sebesar $10 \%$, peningkatan tersebut dapat dilihat dari perbandingan hasil prosentase observasi awal $51 \%$ dengan hasil prosentase siklus I tindakan I $61 \%$. Specific feedback pada saat praktikum dapat meningkatkan self efficacy, hal ini terbukti dari rata-rata hasil angket self efficacy siswa yang meningkat (Dewi, et. al 2018).

Disamping penerapan model pendidikan gerak dan pemberian spesifik feedback ini baru diterapkan, penyampaian konsep dan tujuan dari model pendidikan gerak ini belum sepenuhnya tersampaikan kepada siswa. Peneliti 
mengamati siswa masih seperti kebingungan saat melakukan aktivitas melompat melalui gerak lokomotor dengan penerapan model pendidikan gerak, karena model pendidikan gerak ini lebih menekankan pada pengajaran konsep dan komponen gerak. Menurut Mahendra (2015) model pendidikan gerak adalah "sebuah model pembelajaran dalam Penjas yang menekankan pada pengajaran konsep dan komponen gerak. Berbeda dengan model pembelajaran Penjas yang umumnya mengajarkan berbagai cabang olahraga dengan seluruh teknik dasar, peraturan, serta strateginya, namun dalam pendidikan gerak anak tidak diperkenalkan dengan konsep dan komponen olahraga".

Pada siklus I tindakan II, peningkatan keterampilan melompat siswa melalui model pendidikan gerak aktivitas lokomotor melalui pemberian spesifik feedback meningkat sebesar $21 \%$, peningkatan tersebut dapat dilihat dari perbandingan hasil prosentase observasi awal sebesar $51 \%$ dengan hasil prosentase siklus I tindakan sebesar $72 \%$. Dalam penerapan model pendidikan gerak, guru tidak selalu mendemonstrasikan tugas gerak kepada siswa. Peningkatan terjadi karena siswa sudah mulai menikmati proses pembelajara yang diberikan oleh guru dengan menggunakan model pendidikan gerak, terbukti dari hasil catatan lapangan dan video yang diambil selama proses penelitian berlangsung menunjukan adanya perbedaan tingkah laku yang ditunjukan oleh siswa, dan siswa juga merasa mulai dihargai karena setiap siswa mendapatkan perhatian oleh guru.

Pada siklus II tindakan I, peningkatan keterampilan melompat siswa melalui model pendidikan gerak aktivitas lokomotor melalui pemberiaan spesifik feedback meningkat sebesar $36 \%$, peningkatan tersebut dapat dilihat dari perbandingan hasil prosentase observasi awal $51 \%$ dengan hasil prosentase siklus II tinda-kan I sebesar $87 \%$. Penerapan model pendidikan gerak aktivitas lokomotor melalui pemberian spesifik feedback sudah terlihat mampu meningkatkan keterampilan melompat siswa, dikarenakan secara bertahap pemberian aktivitas dilakukan sesuai dengan rencana yang telah ditetapkan sebelumnya, sehingga keterampilan siswa berkembang dari setiap per-temuannya.

Pada siklus II tindakan II, peningkatan keterampilan siswa melalui model pendidikan gerak aktivitas lokomotor melalui pemberian spesifik feedback meningkat sebesar $43 \%$, peningkatan tersebut dapat dilihat dari perbandingan hasil prosentase observasi awal yang hanya $51 \%$ dengan hasil prosentase siklus II tindakan 2 sebesar 94\%. Ini karena guru sudah menerapkan model pendidikan gerak dan memberikan umpan balik spesifik kepada siswa sehingga siswa merasa lebih baik lagi dalam melakukan kegiatannya.

Berdasarkan dari hasil temuan siklus I sampai dengan siklus II, berdasarkan hasil temuan di atas, sebelumnya siswa dalam melakukan gerakan melompat masih sangat kaku, banyak yang melakukan awalan dengan lari yang sangat lambat, menolak tidak sesuai dipapan tolak, ketika menolak masih banyak yang tidak bertenaga, sikap melayangnya begitu kurang, dan pada saat mendarat kebanyakan siswa lututnya diluruskan tidak mengeper, dan sangat keras ketika mendarat, namun setelah pemberian tindakan berupa penerapan model pendidikan gerak aktivitas lokomotor dan spe- 
sifik feedback oleh peneliti keterampilan melompat siswa mengalami peningkatan.

Dalam model pendidikan gerak aktivitas lokomotor melalui pemberian spesifik feedback membuat aktivitas pembelajaran mejadi lebih menarik, tidak monoton dan lebih kondusif bagi guru dan siswa kelas 3. Dari setiap siklus dan tindakan suasana pembelajaran pendidikan jasmani semakin membuat siswa menjadi antusias dalam mengikuti pembelajaran, dan setelah tindakan berakhir peneliti melakukan refleksi agar tindakan berikutnya dapat memaksimalkan model pendidikan gerak aktivitas lokomotor melalui pemberian spesifik feedback.

Selain model pendidikan gerak, pemberian spesifik feedback juga sangat penting dalam poses pembelajaran, feedback memiliki banyak manfaat dan sangat berperan positif atas keberhasilan siswa dalam belajar. Dengan pemberian feedback atau umpan balik yang tepat diharapkan siswa dapat mencapai tujuan pendidikan yang diinginkan. Feedback merupakan salah satu aspek penting dalam belajar keterampilan gerak dan penampilan olahraga. Berdasarkan temuan di atas, dapat disimpulkan bahwa salah satu cara untuk meningkatkan keterampilan melompat siswa kelas 3 sekolah dasar, yaitu dengan menerapkan model pendidikan gerak aktivitas lokomotor melalui pemberian spesifik feedback, hal ini sesuai dengan hipotesis tindakan yang telah peneliti sebutkan.

\section{KESIMPULAN}

Terdapat peningkatan keterampilan melompat pada pembelajaran aktivtas lokomotor melalui model pendidikan gerak dan pemberian spesifik feedback.

\section{DAFTAR PUSTAKA}

Agustini, I, dkk. (2017). Peningkatan Keterampilan Gerak Dasar Lokomotor menggunakan Metode Bermain dalam Pembelajaran Pendidikan Jasmani Siswa Kelas III C SDN Krian 3 Kabupaten Sidoarjo [online], vol 26 (2). Tersedia di http://journal.um.ac.id/ index.php/pendidikan-jasmani/article/ view/7502

Aloysius, Dkk. (2014). Peningkatan Pembelajaran Teknik Dasar Lompat Jauh melalui Media Alat Praga di Sekolah dasar Negeri 12 Temiasio [online], vol. 1(1). Tersedia di https://jurnal.untan.ac.id

Arikunto, S. (2006). Prosedur Penelitian suatu pendekatan Praktik. Jakarta: Riska Cipta.

Budiman, D. (2009). Perbandingan Pengaruh Pemberian Umpan Balik Positif dan Umpan Balik Netral dalam Pembelajaran Pendidikan Jasmani terhadap Pembentukan Konsep Diri yang Positif Siswa SD [online], vol. 1(1). Tersedia di https://jurnal.upi.edu/2155 view/1035/perbandinga-pengaruhpemberian-umpan-balik-positif-danumpan-balik-netral-dalampembelajaran-pendidikan-jasmaniterhadap-pembentukan-konsep-diriyang-positif-siswa-sd.html

Dewi, Ayu Candra. dkk. (2018). Pengaruh Spesifik Feedback terhadap Self Efficacy Siswa pada Praktikum Kimia Kelas XI MIA SMAN 1 Sungai Kunyit. dalam Jurnal pendidikan dan pembelajaran [online], vol. 7 (10). Tersedia di http:// jurnal.untan.ac.id

Elmubarok, Z. (2009). Membumikan Pendidikan Nilai Mengumpulkan Yang Terserak, Menyambung Yang Terputus, dan Menyatukan yang Tercerai. Bandung: Alfabeta.

Faridah, E. (2016). Mengajar Pendidikan Jasmani Melalui Permainan "Ide Kreatif Mengoptimalkan Aspek Pedagogis". dalam Jurnal Ilmu Keolahragaan [online], vol.15 (2). Tersedia di https:// jurnal.unimed.ac.id

Mahendra, A. (2015). Filsafat Pendidikan Jasmani Dasar-Dasar Pembelajaran Penjas 
di Sekolah Dasar. Bandung: CV. Bintang Warliartika

Mahendra, A. (2017). Model Pendidikan Gerak Implementasi Pendidikan Jasmani di Skolah Dasar. Bandung: Prodi PGSD Penjas-FPOK UPI.

Suherman, a. (2009). revitalisasi pengajaran dalam pendidikan jasmani. bandung: cv. bintang warliartika.

Undang - undang dasar nomor 20 tahun 2003 tentang sistem pendidikan nasional.

Windarsih, A. (2016). Aplikasi Teori Umpan Balik (Feedback) dalam Pembelajaran Motorik pada Anak Usia Dini [online], vol 2 (1). tersedia di http://ejournal.stkipsiliwangi.ac.id/index.php/ tunas-siliwangi/article/view/306 